\title{
STUDY OF THE GLUCOSE, ELECTROLYTES, ENZYMES AND NITROGEN COMPONENTS OF FOWL SEMINAL PLASMA*
}

\author{
MARY HAMMOND, M. A. BOONE AND B. D. BARNETT \\ Poultry Science Department, Clemson University, \\ Clemson, South Carolina, U.S.A.
}

(Received 31st July 1964, revised 16th December 1964)

Summary. This study was undertaken to determine some of the biochemical components of fowl seminal plasma. The semen used in this investigation was collected by artificial ejaculation of 18-month-old White Plymouth Rock males.

Glucose concentration was $74 \cdot 2 \pm 7 \cdot 8 \mathrm{mg}$ glucose $/ 100 \mathrm{ml}$ of cock seminal plasma. Several enzyme analyses were conducted, using incubation, colorimetry and titration techniques. The enzyme concentrations found were as follows: acid phosphatase, $106 \pm 6.5$ sJR units; alkaline phosphatase, $6.7 \pm 0.83$ sJR units; glutamic pyruvic transaminase, $12 \cdot 8 \pm 1.4$ GPT units; glutamic oxalic transaminase, $560 \pm 69 \cdot 6$ GoT units; lactic dehydrogenase, $4610 \pm 251 \mathrm{LDH}$ units and leucine amino peptidase, $2474 \pm 436$ LAP units. Lipase was not found to be present under the conditions of these analyses. Nitrogen concentration as determined by micro-Kjeldahl method averaged $180 \mathrm{mg} / 100 \mathrm{ml}$ of fowl seminal plasma. Free amino acids found were glutamic acid, glycine, arginine, alanine, serine and methionine. Bound amino acids found were $\alpha$ - or $\beta$-alanine, serine, threonine, valine, methionine, tryptophan, leucine (isoleucine, norleucine or leucine) aspartic and glutamic acids, arginine, lysine, histidine, cystine, phenylalanine tyrosine, proline and several unidentified spots.

\section{INTRODUCTION}

Although reproductive failures are a source of concern to poultrymen, the biochemical composition of fowl seminal plasma has received little attention. Harris \& Wilcox (1962) found glucose and fructose were utilized to a much greater extent than other carbohydrates when added to chicken semen. Glucose concentration was much higher than that of other carbohydrates found by DeMuelenaere \& Quicke (1959), Yoshida \& Masuda (1962), Nishiyama (1957) and Mann (1954). Alkaline and acid phosphatase concentrations were determined by Bell \& Lake (1962) and Wilcox (1961). Other enzymes of fowl seminal plasma analysed in this study have not been previously reported in the

* Published with permission of the Director of the South Carolina Agricultural Experiment Station as Technical Contribution No. 496. 
literature. Electrolytes of fowl seminal plasma were studied by Lake, Butler, McCallum \& MacIntyre (1958) and Takeda (1959). Nitrogen compounds have been studied by Pytasz \& Klymiuk (1961) and Wales, Scott \& White (1961). The amino acids were studied by Chubb \& Cooper (1962), Goldberg, Pence \& Norman (1961) and Yoshida \& Masuda (1962).

The object of this experiment was to identify some of the biochemical components of fowl seminal plasma. These components include glucose, nitrogen, some of the electrolytes, enzymes and identification of some of the amino acids, both bound and free.

\section{METHODS}

Semen from each of six White Plymouth Rock males, 18 months old, was collected three times weekly by the method of Burrows \& Quinn (1937), with at least 1 day between collections. The volumes were determined by using a $1 \mathrm{ml}$ tuberculin syringe. Spermatozoa count employed the haemocytometer technique, and motility (percentage showing movement) and vigour as used by Boone \& Huston (1963). These measurements were made at room temperature, approximately $25^{\circ} \mathrm{C}$, between $30 \mathrm{~min}$ and $1 \mathrm{hr}$ after collection. Seminal plasma was then separated from the spermatozoa by centrifugation at approximately $2000 \mathrm{~g}$ for $5 \mathrm{~min}$ and decantation of the seminal plasma to another tube. The centrifugation and decantation were repeated to insure removal of all spermatozoa. Samples were frozen at $0^{\circ} \mathrm{F}$. The three seminal plasma samples from each male were pooled weekly. All samples were kept well below room temperature prior to the analyses by immersing them in an ice bath. Glucose analysis was made by the method of Huffman (1937) as modified for use on the Technicon auto analyser (1960).

Acid and alkaline phosphatases were analysed by the method of Shinowara, Jones \& Reinhart (1942). Each unit was equal to the amount of phosphatase that liberates $1 \mathrm{mg}$ of inorganic phosphorus from $\beta$-glycerolphosphate in $1 \mathrm{hr}$ under conditions of test. Lactic dehydrogenase was determined by the method of Cabaud \& Wroblewski (1958). Each unit is equivalent to the amount of enzyme that would cause a decrease in optical density of $0.001 / \mathrm{min}$ in a reaction mix of $3 \mathrm{ml}$ of sample. Lipase determinations employed the method of Tietz, Borden \& Stepleton (1959). Lipase units are equal to the number of $\mathrm{ml}$ of 0.05 $\mathrm{N}$-sodium hydroxide required to neutralize the free fatty acid liberated by the lipase in the sample during a $6 \mathrm{hr}$ incubation period. Leucine amino peptidase (LAP) was determined by Sigma's (1962) modification of the method of Goldbarg \& Rutenburg (1958). One LAP unit is equivalent to $0.0417 \mu \mathrm{g} \beta$-naphthylamine liberated in $1 \mathrm{hr}$ at $37^{\circ} \mathrm{C}$. Glutamic oxaloacetic (GOT) and glutamic pyruvic (GPT) transaminases were determined by the method of Reitman \& Frankel (1957). Each GOT and GPT unit is equivalent to $1 \mu \mathrm{g}$ of oxaloacetic acid and pyruvate respectively produced under conditions of the test.

Electrolyte concentrations, except chloride, were determined using a flame photometer. Chloride concentration required the use of a chloridimeter. Nitrogen concentration of composite samples in duplicate were determined by the micro-Kjeldahl (A.O.A.C., 1955) method.

Both bound and free amino acids of the fowl seminal plasma are identified 
by the method of Chubb \& Cooper (1962). This required the use of two dimensional chromatography (Block \& Weiss, 1956). n.Butanol, glacial acetic acid and water $(4: 1: 1)$ was the first solvent and pyridine and water $(4: 1)$ was the second.

An analysis of variance (Steel \& Torrie, 1960) was made for differences among males. Estimates of correlation of glucose, enzymes and electrolytes with percentages of motility, sperm vigour and number of sperm were made. Standard errors of the mean follow the average glucose, electrolyte and enzyme concentrations.

\section{RESULTS AND DISGUSSION}

Carbohydrate and enzyme analyses of semen indicate the metabolism of the sperm to be concerned mainly with the glycolytic scheme (Mann, 1954). He found glucose to be the major carbohydrate present with small amounts of fructose and trace amounts of others. In this study, $74 \cdot 2 \pm 7 \cdot 8 \mathrm{mg}$ of glucose (Table 1) per $100 \mathrm{ml}$ of seminal plasma were found. Mann (1954) found

\section{TABLE 1}

AVERAGE GLUCOSE CONCENTRATION IN THE SEMINAL PLASMA OF THE FOWL BASED ON FOUR ANALYSES PER MALE*

\begin{tabular}{c|c}
\hline Male No. & $m g / 100 m l$ \\
\hline 4584 & $88 \cdot 00 \pm 11 \cdot 54$ \\
4622 & $56 \cdot 00 \pm 13.33$ \\
4639 & $88.00 \pm 25 \cdot 10$ \\
4108 & $90 \cdot 00 \pm 16 \cdot 33$ \\
4544 & $58 \cdot 67 \pm 13 \cdot 33$ \\
Weighted average & $74.15 \pm 7 \cdot 80$ \\
\hline
\end{tabular}

* \pm Standard error of the mean.

7.7 to $81 \mathrm{mg}$ of glucose $/ 100 \mathrm{ml}$ of fowl semen. Harris \& Wilcox (1962) found that glucose was utilized as a source of spermatozoa energy when added to diluted semen as measured by changes in $\mathrm{pH}$, carbohydrate disappearance and lactic acid production.

Some phosphatases, both acid and alkaline, are involved in the hydrolysis of carbohydrates. Acid phosphatase, in this study, averaged $106 \cdot 3 \pm 6 \cdot 5$ sJR units (Table 2).

Alkaline phosphatase averaged $6 \cdot 7 \pm 0 \cdot 8 \mathrm{sJR}$ units $/ \mathrm{ml}$. Bell \& Lake (1962) also found the acid phosphatase values to be much higher than the alkaline phosphatase.

No previous analyses of transaminase, peptidase, lactic dehydrogenase or lipase concentrations in fowl semen or seminal plasma were found in the literature. The average concentration of glutamic pyruvic transaminase (Table 2) was $12 \cdot 8 \pm 1.4$ units. Lactic dehydrogenase averaged $4610 \pm 251$ units/ml of seminal plasma (Table 2). This enzyme catalyses the following reaction: pyruvic acid + DPNH $\rightleftharpoons$ lactic acid + DPN (White, Handler, Smith 


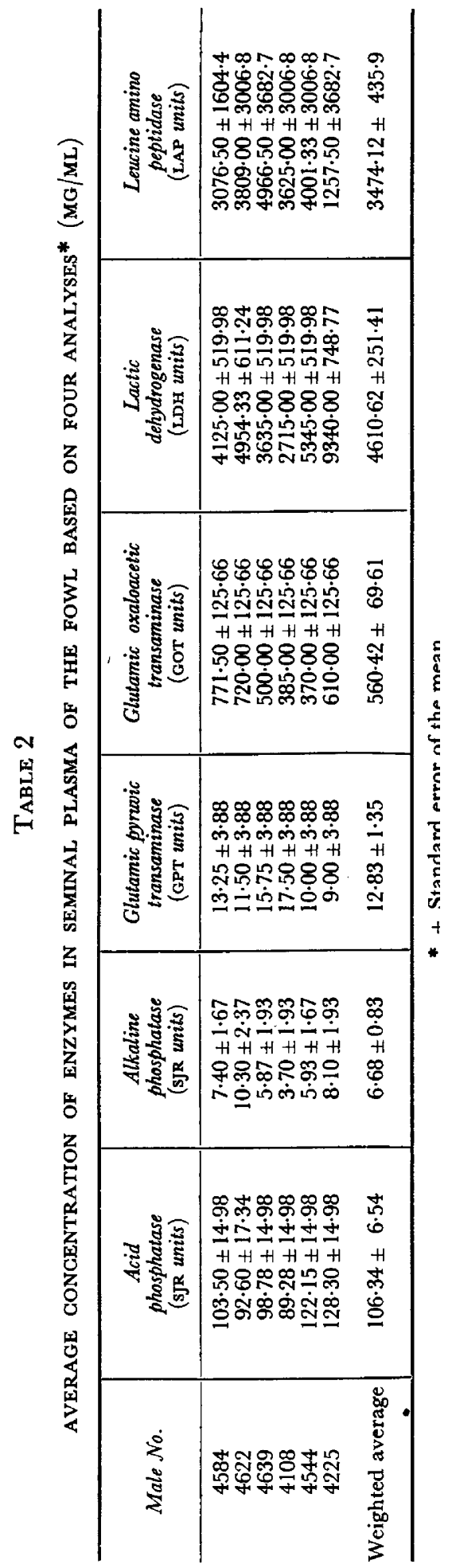


\& Stetten, 1959). This is an important reaction involved in anaerobic energy metabolism. The average concentration of glutamic oxaloacetic transaminase, also known as glutamic aspartic transaminase, was $560 \pm 69.6$ units. This enzyme catalyses the following reaction: aspartic $+\alpha$ keto glutaric acid $\rightleftharpoons$ oxaloacetic+glutamic acid. Aspartic and oxaloacetic acids are parts of the Krebs cycle (White et al., 1959). Leucine amino peptidase averaged $3474 \pm 436$ units (Table 2). This enzyme hydrolyses peptide chains at the leucine amino group. Lipase is an enzyme catalysing the breakdown of fats to fatty acids and glycerol. This enzyme was not found in the two samples of seminal plasma examined. This indicates that fat metabolism may be very low or absent in spermatozoa.

Electrolytes play an important role in homeostasis. Both osmotic pressure and $\mathrm{pH}$ are greatly affected when these electrolytes are not in correct proportion or balance. The ions of sodium, potassium, chloride, calcium, bicarbonate,

TABLE 3

AVERAGE GONGENTRATION OF ELECTROLYTES IN SEMINAL PLASMA OF THE FOWL BASED ON FOUR ANALYSES* (MG/100 ML)

\begin{tabular}{|c|c|c|c|c|}
\hline Male No. & $\mathcal{N a}$ & $\mathrm{Ca}$ & $K$ & $C l$ \\
\hline $\begin{array}{l}4584 \\
4622 \\
4639 \\
4108 \\
4544 \\
4225\end{array}$ & $\begin{array}{l}385 \cdot 25 \pm 25 \cdot 77 \\
334 \cdot 08 \pm 25 \cdot 77 \\
331 \cdot 78 \pm 25 \cdot 77 \\
381 \cdot 23 \pm 25 \cdot 77 \\
276 \cdot 58 \pm 25 \cdot 77 \\
310 \cdot 50 \pm 29 \cdot 76\end{array}$ & $\begin{array}{l}6 \cdot 80 \pm 0.97 \\
6 \cdot 50 \pm 0.97 \\
7 \cdot 00 \pm 0.97 \\
8 \cdot 50 \pm 0.97 \\
5 \cdot 75 \pm 0.97 \\
7 \cdot 87 \pm 1 \cdot 11\end{array}$ & $\begin{array}{l}45.63 \pm 8 \cdot 61 \\
54 \cdot 20 \pm 8 \cdot 61 \\
43.08 \pm 8 \cdot 61 \\
38.43 \pm 8 \cdot 61 \\
49 \cdot 70 \pm 8 \cdot 61 \\
35.63 \pm 9.96\end{array}$ & $\begin{array}{l}553 \cdot 25 \pm 32 \cdot 9 \\
369 \cdot 50 \pm 46 \cdot 6 \\
563 \cdot 67 \pm 38 \cdot 1 \\
498 \cdot 25 \pm 32 \cdot 9 \\
478 \cdot 75 \pm 32 \cdot 9 \\
401 \cdot 00 \pm 65 \cdot 9\end{array}$ \\
\hline Weighted average & $337 \cdot 70 \pm 17 \cdot 19$ & $7 \cdot 03 \pm 0 \cdot 40$ & $44 \cdot 83 \pm 2 \cdot 76$ & $497 \cdot 33 \pm 27 \cdot 7$ \\
\hline
\end{tabular}

* \pm Standard error of mean.

magnesium, phosphate and sulphate are involved in homeostasis of spermatozoa as indicated by Mann (1954). Calcium averaged $7 \cdot 0 \pm 0.4 \mathrm{mg} / 100 \mathrm{ml}$ (Table 3 ). This concentration was lower than the $8.4 \mathrm{mg}$ of calcium/100 $\mathrm{ml}$ of fowl seminal plasma reported by Takeda (1959) and $9 \mathrm{mg} / 100 \mathrm{ml}$ reported by Lake et al. (1958). Potassium concentration averaged $44 \cdot 8 \pm 2 \cdot 8 \mathrm{mg} / 100 \mathrm{ml}$ (Table 3 ). This was within the range (39 to $49 \mathrm{mg} / 100 \mathrm{ml}$ ) found by Lake et al. (1958). Takeda (1959), however, found $29.7 \mathrm{mg} / 100 \mathrm{ml}$. Sodium averaged $338 \pm 17$ $\mathrm{mg} / 100 \mathrm{ml}$ (Table 3), which agreed closely with both Lake et al. (1958) and Takeda (1959) who found 379 and 332.5 to $346 \mathrm{mg} / 100 \mathrm{ml}$ respectively. Chloride averaged $497 \pm 27.7 \mathrm{mg} / 100 \mathrm{ml}$ (Table 3 ). This concentration was much higher than that reported by Lake et al. (1958) who found 197 to 212 $\mathrm{mg} / 100 \mathrm{ml}$. Concentrations of the various electrolytes and other components and volumes of semen may vary, since all investigators did not employ the same ejaculation technique and breeds of fowl or analytical methods. In these studies the volume of seminal fluid/ejaculate averaged $2.07 \mathrm{ml}$, while Sturkie (1954) reported an average of $0.75 \mathrm{ml} /$ ejaculate.

Total nitrogen (Table 4) as determined by micro-Kjeldahl method averaged $180 \mathrm{mg} / 100 \mathrm{ml}$ of seminal plasma. Pytasz \& Klymiuk (1961) using paper 
electrophoresis found $593 \mathrm{mg}$ of nitrogen/100 ml. The differences may, in part, be due to presence of urates (uric acid) in the latter, a dilution factor in the former due to collection technique, or the difference in analytical methods used.

Protein components were studied by amino acid analyses. In this study, $\alpha-$ or $\beta$-alanine, serine, threonine, valine, methionine, tryptophan, leucine (isoleucine, norleucine, or leucine), aspartic and glutamic acids, arginine, lysine, histidine, cystine, phenylalanine, tyrosine, proline and several unidentified spots were noted in the bound amino acid fraction. In addition to these, Chubb \& Cooper (1962) found glycine, glutamine, taurine, asparagine, citrulline and $\alpha$-aminobutyric acid. Free amino acids found were glutamic acid, $\alpha$ - or $\beta$-alanine, glycine, serine, arginine, methionine, leucine and several unidentified spots. Chubb \& Cooper (1962) found $80 \%$ glutamic acid and some $\alpha$-alanine, aspartic acid, glycine and serine. Goldberg et al. (1961), found $79 \%$ glutamic acid, along with glycine, arginine, alanine and trace amounts of other free amino acids.

TABLE 4

\begin{tabular}{c|c} 
NITROGEN & $\begin{array}{c}\text { CONCENTRATION } \\
\text { SEMINAL PLASMA }\end{array}$ \\
\hline Week & $\begin{array}{c}\text { Nitrogen } \\
(\mathrm{mg} / 100 \mathrm{ml})\end{array}$ \\
\hline 1 & 218 \\
2 & 127 \\
3 & 184 \\
4 & 162 \\
Average & 180 \\
\hline
\end{tabular}

Based on micro-Kjeldahl determination, using composite samples run in duplicate.

This large amount of glutamic acid would be expected since, as previously noted, glutamic acid is an end product of glutamic-oxaloacetic and pyruvic transaminase reactions.

Since glucose, enzymes and electrolytes play an important part in the metabolism of the spermatozoa, the correlations of these biochemical components with the percentage of motile spermatozoa, spermatozoal vigour and number of spermatozoa were estimated. It is apparent from Tables 5 and 6 that the correlations were significant in only four cases. Table 5 shows a highly significant positive correlation between the amount of lactic dehydrogenase/spermatozoa and the percentage of motile spermatozoa. This enzyme may play an important role in the spermatozoon's anaerobic energy metabolism during the quiescent period of the spermatozoon's life, and thus the amount of lactic dehydrogenase would increase as the number of active spermatozoa increases.

The speed (vigour) with which the spermatozoon moved across the microscopic field apparently bore no significant relationship to the quantity of any of the biochemical components studied (Table 5).

Table 6 shows a highly significant positive correlation between the amount of acid phosphatase and the number of sperm. The highly significant negative 
correlation between numbers of spermatozoa and glucose suggests the utilization of glucose by the spermatozoa. A significant negative correlation between the concentration of chloride in seminal plasma and the number of spermatozoa was found. This suggests the possibility of the chloride ions shifting into the spermatozoa while carbon dioxide is lost.

\section{TABLE 5}

CORRELATION COEFFICIENT OF THE BIOCHEMICAL COMPONENTS OF SEMINAL PLASMA/SPERM WITH PER GENT MOTILE SPERM AND SPERM VIGOUR IN FOWL SEMEN

\begin{tabular}{l|c|c}
\hline \multicolumn{1}{c|}{$\begin{array}{c}\text { Biochemical } \\
\text { component }\end{array}$} & $\begin{array}{c}\text { Motile sperm } \\
(\%)\end{array}$ & $\begin{array}{c}\text { Vigour } \\
r\end{array}$ \\
& $r$ & \\
\hline Glucose & -0.4412 & -0.3130 \\
Acid phosphatase & -0.1692 & -0.1602 \\
Alkaline phosphatase & -0.1956 & -0.3200 \\
Leucine aminopeptidase & -0.0088 & -0.2385 \\
Lactic dehydrogenase & $0.5515 *$ & 0.2012 \\
Glutamic oxaloacetic transaminase & -0.1911 & -0.1495 \\
Glutamic pyruvic transaminase & $0 \cdot 1630$ & 0.1411 \\
Sodium & -0.1207 & -0.0429 \\
Calcium & -0.1296 & $0 \cdot 1516$ \\
Potassium & -0.1794 & -0.1515 \\
Chloride & -0.1581 & -0.0843 \\
\end{tabular}

* Significant at the 0.01 level.

TABLE 6

CORRELATION COEFFICIENT OF THE BIOCHEMICAL COMPONENTS/ML OF SEMINAL PLASMA WITH NUMBER OF SPERMATOZOA/ML IN FOWL SEMEN

\begin{tabular}{l|c}
\hline \multicolumn{1}{c|}{ Biochemical component } & $r$ \\
\hline Glucose & $-0.7236 \dagger$ \\
Acid phosphatase & $0.6346 \dagger$ \\
Alkaline phosphatase & -0.0741 \\
Leucine aminopeptidase & -0.3113 \\
Lactic dehydrogenase & $0 \cdot 3599$ \\
Glutamic oxaloacetic transaminase & 0.0472 \\
Glutamic pyruvic transaminase & $-0 \cdot 1977$ \\
Sodium & -0.3020 \\
Calcium & -0.1413 \\
Potassium & $0 \cdot 1596$ \\
Chloride & $-0.5235 *$ \\
& \\
\hline
\end{tabular}

* Significant at the 0.05 level.

$\dagger$ Significant at the 0.01 level.

AGKNOWLEDGMENTS

The authors would like to express their appreciation to Dr D. E. Turk for his many helpful suggestions, to Dr W. P. Byrd for his aid in the statistical analysis and to the Greenville General Hospital, Greenville, South Carolina, for the use of specialized equipment. 


\section{REFERENCES}

Association of Official Agrigultural Chemists (1955) Official methods of analysis, 8th edn. Washington, D.C.

BeLI, D. J. \& LAKE, P. E. (1962) A comparison of phosphomonoesterase activities in the seminal plasmas of the domestic cock, turkey tom, boar, bull, buck, rabbit, and of man. $\mathcal{J}$. Reprod. Fertil. $3,363$.

Block, R. J. \& Weiss, D. W. (1956) Amino acid handbook. Thomas, Springfield.

BooNE, M. A. \& Huston, T. M. (1963) Effects of high temperature on semen production and fertility in the domestic fowl. Poult. Sci. 42, 670.

Burrows, W. H. \& Quin, J. P. (1937) The collection of spermatozoa from the domestic fowl and turkey. Poult. Sci. 16, 19.

Cabaud, P. G. \& Wroblewski, F. (1958) Colorimetric measurement of lactic dehydrogenase activity in body fluids. Amer. F. clin. Path. 30, 234.

Chubs, L. G. \& Cooper, D. M. (1962) Amino acids in fowl seminal plasma. F. Reprod. Fertil. 4, 7.

DeMuelenaere, H.J. H. \& Quicke, G. V. (1959) The biochemistry of cock semen. I. Seminal sugars. S. Afr. F. agric. Sci. $1,67$.

Goldbarg, J. A. \& Rutenburg, A. M. (1958) The colorimetric determination of leucine amino peptidase in urine and serum of normal subjects and patients with cancer and other diseases. Cancer, $11,283$.

Goldberg, E., Pence, V. W. \& Norman, C. (1961) The distribution of free amino acids in cock and bull seminal plasma and spermatozoa. Amer. Zool. 1, 356.

Harris, G. C. JR. \& Wilcox, F.H. (1962) The carbohydrate metabolism of chicken semen. Poult. Sci. 41, 409.

HuffMan, W. S. (1937) A rapid photoelectric method for the determination of glucose in blood and urine. F. biol. Chem. 120, 51 .

Lake, P. E., Butler, E. J. McGallum, J. W. \& Macintyre, I. J. (1958) A chemical analysis of the seminal and blood plasmas of the cock. Quart. F. exp. Physiol. 43, 309.

Mann, T. (1954) The biochemistry of semen. Wiley, New York.

NishiYaMA, H. (1957) On the characteristics of the transparent fluids. F. Fac. Agric., Kyushu Univ. 11, 63.

Pytasz, M. \& Klymiux, B. (1961) Proteins and nonprotein nitrogen in the semen of the domestic fowl. Med. Weterynar, Poland, 17, 437 (cited in Chem. Abstr. 58, 5, 1963).

Reitman, S. \& Frankel, S. (1957) Colorimetric method for the determination of serum transaminase activity. Amer. F. clin. Path. 28, 56.

Shinowara, G. Y., Jones, L. W. \& Reinhart, H. L. JR. (1942) The estimation of serum inorganic phosphate and 'acid' and 'alkaline' phosphatase activity. F. biol. Chem. 142, 921.

Sigma (1962) The colorimetric determination of leucine amino peptidase. Tech. Bull. 250, Sigma Chemical Co, St Louis 18, Mo.

Steel, R. D. \& ToRrIe, J. H. (1960) Principles and procedures of statistics. McGraw-Hill, New York.

STURkie, P. D. (1954) Avian physiology. Comstock Publishing Co, Ithaca, New York.

TAkedA, A. (1959) Studies on the cock semen. I. Na, K and Ca levels of seminal plasma. Sci. Bull. Fac. Agric., Kyushu Univ. 9, 55.

TeChnicon Instrumenrs CoRP. (1960) Glucose determinations. Ghauncy, New York.

Tietz, N. W., Borden, T. \& Stepleton, J. D. (1959) Amer. F. clin. Path. 31, 148.

Wales, R. G., Scott, T. W. \& White, L. G. (1961) Biuret reactive materials in semen. Aust. J. exp. Biol. med. Sci. 39, 455 .

White, A., Handler, P., Smith, E. L. \& Stetten, DeWitr. (1959) Principals of biochemistry. McGrawHill, New York.

WILcox, F. H. (1961) Phosphatases in chicken semen. 7. Reprod. Fertil. 2, 148.

YoshIDA, S. \& MASUDA, H. (1962) Studies on the composition and metabolism of fowl semen. Zootechn. e Vet. 17, 528 (cited in Chem. Abstr. 58, 1750, 1963). 